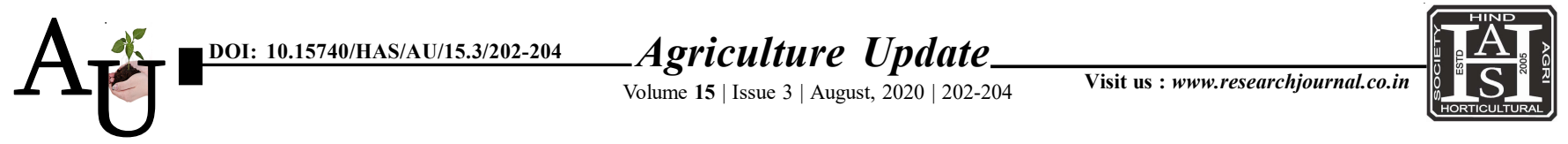

ISSN-0973-1520

\title{
Research Article: Impact of agriclinic activities and relationship between socio-economic characteristics of beneficiaries
}

\section{J. H. Gaikwad}

Article Chronicle : Received :

22.04.2020;

Revised:

11.06.2020;

Accepted :

13.07.2020

KEY WoRDS :

Relationship, Impact, Agriclinic centers
SUMMARY : Agriclinic centers were firstly started by Government of Maharashtra in 1997-98. The Department of Agriculture of Maharashtra state aim's to establish 232 Agriclinic center's in forth coming years. The Government of Maharashtra expend Rs. 15 lakhs on each Agriclinic centers. The present study was conducted in Ahmednagar district was purposively selected for the present study, because there are 7 agriclinic i.e. more in number as compared to other districts. Majority of the respondent beneficiaries opinioned that training programme of agriclinic helps in providing self employment opportunities to the rural youth (73.34\%). It is observed that there was age is negatively but statistically significant correlated with impact of agriclinic activities. Education, size of land holding, annual income, social participation, sources of information, cosmopoliteness, risk orientation and extent of participation of beneficiaries had positive and statistically significant correlation with impact of agriclinic activities. Only size of family is non-significant with impact of agriclinic activities.

How to cite this article : Gaikwad, J.H. (2020). Impact of agriclinic activities and relationship between socioeconomic characteristics of beneficiaries. Agric. Update, 15(3): 202-204; DOI : 10.15740/HAS/AU/15.3/202204. Copyright@2020: Hind Agri-Horticultural Society.
Author for correspondence:

\section{J. H. Gaikwad} Department of Agricultural Extension, Agriculture Technology

School, Puntamba,

Rahata, Ahmednagar

(M.S.) India

Email: jh_gaikwad@

rediffmail.com 